\title{
Hybrid Monoterpenoid Indole Alkaloids Obtained as Artifacts from Rauvolfia tetraphylla
}

Yuan Gao • Dong-Sheng Zhou • Ping Hai •

Yan Li $\cdot$ Fei Wang

Received: 2 September 2015/Accepted: 24 September 2015/Published online: 29 September 2015

(C) The Author(s) 2015. This article is published with open access at Springerlink.com

\begin{abstract}
Five new hybrid monoterpenoid indole alkaloids bearing an unusual 2,2-dimethyl-4-oxopiperidin-6-yl moiety, namely rauvotetraphyllines F-H (1, 3, 4), 17-epi-rauvotetraphylline F (2) and 21-epi-rauvotetraphylline $\mathrm{H}(\mathbf{5})$, were isolated from the aerial parts of Rauvolfia tetraphylla. Their structures were established by extensive spectroscopic analysis. The new alkaloids were evaluated for their cytotoxicity in vitro against five human cancer cell lines.
\end{abstract}

Graphical Abstract

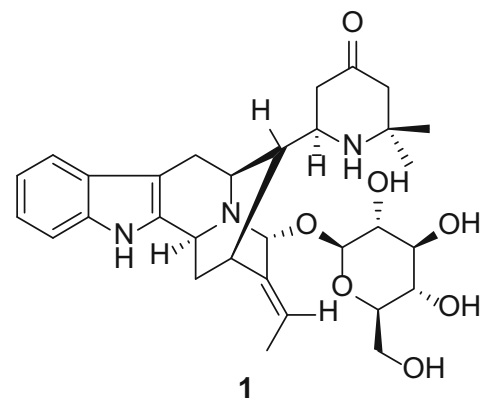

1

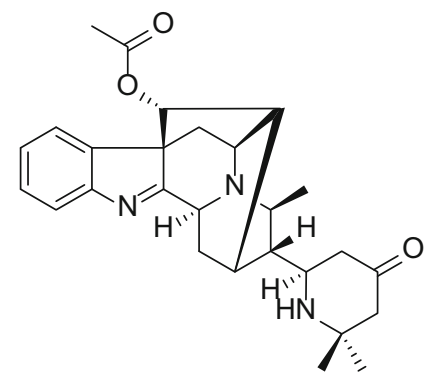

4

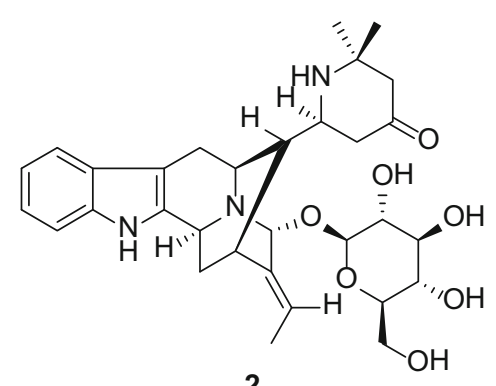

2

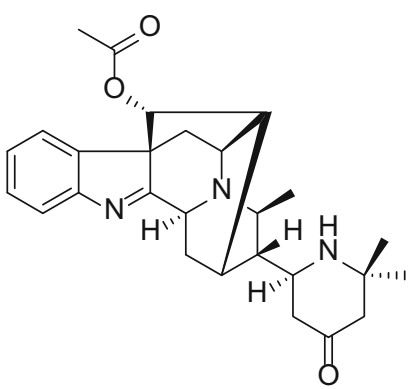

5

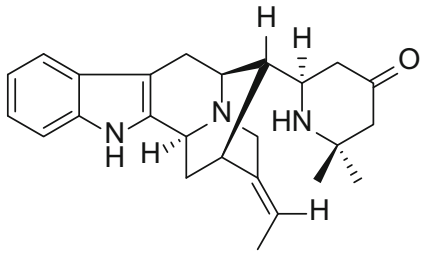

3

Electronic supplementary material The online version of this article (doi:10.1007/s13659-015-0074-2) contains supplementary material, which is available to authorized users.

Y. Gao - D.-S. Zhou · P. Hai · F. Wang (ه)

BioBioPha Co., Ltd., Kunming 650201, People's Republic of China

e-mail: f.wang@mail.biobiopha.com
Y. Gao

Department of Chemical Engineering, Yibin University, Yibin 644000, People's Republic of China 


\section{Introduction}

Rauvolfia genus of the Apocynaceae family, comprising about 60 species, is mainly distributed in America, Africa, Asia, and Oceania [1]. Plants of this genus are a rich source of monoterpenoid indole alkaloids, which have attracted great interests from biological and therapeutic aspects [2-5]. As part of a BioBioPha [http://www.chemlib.cn] objective to assemble a large-scale natural product library valuable in the discovery of new drug leads from nature, previous chemical study on the ethanolic extract of Rauvolfia tetraphylla had resulted in the isolation of five new indole alkaloids, rauvotetraphyllines A-E [6]. Further investigation of the remaining components led to the isolation of another five new alkaloids bearing an unusual 2,2dimethyl-4-oxopiperidin-6-yl moiety, rauvotetraphyllines $\mathrm{F}-\mathrm{H}(\mathbf{1}, \mathbf{3}, \mathbf{4})$, 17-epi-rauvotetraphylline $\mathrm{F}(\mathbf{2})$ and 21-epirauvotetraphylline $\mathrm{H}(\mathbf{5})$. The present paper describes the isolation, structure elucidation, and cytotoxic evaluation of the new compounds.

\section{Results and Discussion}

Compound 1, obtained as amorphous powder, possessed a molecular formula of $\mathrm{C}_{31} \mathrm{H}_{41} \mathrm{~N}_{3} \mathrm{O}_{7}$, as evidenced by HRESI-MS (pos.) at $\mathrm{m} / z 568.3025$ (calcd for $\mathrm{C}_{31} \mathrm{H}_{42} \mathrm{~N}_{3} \mathrm{O}_{7}$, 568.3022), in combination with NMR spectra (Tables 1 and 3), requiring 13 degrees of unsaturation. In the UV spectrum, two characteristic maxima at 225 and 281 were detected, suggesting the existence of an unsubstituted indole chromophore [7]. The IR spectrum showed the presence of $\mathrm{OH} / \mathrm{NH}\left(3404 \mathrm{~cm}^{-1}\right)$ functionalities. The 1DNMR spectra (Tables 1 and 3) revealed the presence of an unsubstituted indole moiety $\left[\delta_{\mathrm{H}} 7.38(1 \mathrm{H}, \mathrm{d}, J=7.8 \mathrm{~Hz})\right.$, $7.26(1 \mathrm{H}, \mathrm{d}, J=8.0 \mathrm{~Hz}), 7.02(1 \mathrm{H}, \mathrm{dd}, J=8.0,7.3 \mathrm{~Hz})$, and $6.95(1 \mathrm{H}, \mathrm{dd}, J=7.8,7.3, \mathrm{~Hz}) ; \delta_{\mathrm{C}} 139.7(\mathrm{~s}), 138.2(\mathrm{~s})$, 128.9 (s), 121.9 (d), 119.7 (d), 118.5 (d), 111.9 (d), and $104.0(\mathrm{~s})]$, an ethylidene group $\left[\delta_{\mathrm{H}} 1.75(3 \mathrm{H}, \mathrm{d}\right.$, $J=6.9 \mathrm{~Hz})$ and $5.93(1 \mathrm{H}, \mathrm{q}, J=6.9 \mathrm{~Hz}) ; \delta_{\mathrm{C}} 14.3(\mathrm{q})$ and $125.2(\mathrm{~d})]$, and a glucose unit $\left[\delta_{\mathrm{H}} 4.64(1 \mathrm{H}, \mathrm{d}, J=7.9 \mathrm{~Hz})\right.$, $3.29(1 \mathrm{H}, \mathrm{m}), 3.37(1 \mathrm{H}, \mathrm{m}), 3.28(2 \mathrm{H}, \mathrm{m}), 3.60(1 \mathrm{H}, \mathrm{dd}$, $J=11.9,4.9 \mathrm{~Hz})$, and $3.74(1 \mathrm{H}, \mathrm{dd}, J=11.9,1.6 \mathrm{~Hz}) ; \delta_{\mathrm{C}}$ 103.2 (d), 78.0 (d), 77.9 (d), 75.4 (d), 71.4 (d), and 62.7 (t)]. Comparison of its ${ }^{13} \mathrm{C}$ NMR data with those of

Y. Li

State Key Laboratory of Phytochemistry and Plant Resources in West China, Kunming Institute of Botany, Chinese Academy of Sciences, Kunming 650201, People's Republic of China rauvotetraphylline $B$ [6] revealed a remarkable resemblance except for a prominent difference as follows: the carbon signals assigned to 4,6-dimethylpyrid-2-yl unit in rauvotetraphylline $\mathrm{B}$ were not present, and there was a set of newly arisen resonances $\left[\delta_{\mathrm{C}} 56.5(\mathrm{~d}), 47.4(\mathrm{t}), 213.2(\mathrm{~s})\right.$, $55.7(\mathrm{t}), 55.5(\mathrm{~s}), 25.6(\mathrm{q})$, and $31.9(\mathrm{q})$ ] determined as a

Table $1{ }^{1} \mathrm{H}$ NMR Data for Compounds $\mathbf{1}-\mathbf{3}$ ( $\delta$ in ppm, $J$ in $\mathrm{Hz}$ )

\begin{tabular}{|c|c|c|c|}
\hline No. & $\mathbf{1}^{\mathrm{a}}$ & $2^{\mathrm{a}}$ & $3^{\mathrm{b}}$ \\
\hline 3 & $\begin{array}{l}4.67(\mathrm{dd}, 10.1 \text {, } \\
2.1)\end{array}$ & $4.70(\mathrm{br} \mathrm{d}, 10.5)$ & 4.07 (br d, 10.4) \\
\hline 5 & $2.88(\mathrm{dd}, 7.0,5.3)$ & $3.20(\mathrm{dd}, 7.0,5.5)$ & $2.92(\mathrm{dd}, 7.5,5.3)$ \\
\hline $6 \alpha$ & $\begin{array}{l}3.10(\mathrm{dd}, 15.2, \\
5.3)\end{array}$ & $\begin{array}{l}3.16(\mathrm{dd}, 15.4, \\
5.5)\end{array}$ & $\begin{array}{l}3.08(\mathrm{dd}, 15.3, \\
5.3)\end{array}$ \\
\hline $6 \beta$ & $2.64(\mathrm{~d}, 15.2)$ & $2.91(\mathrm{~d}, 15.4)$ & $2.53(\mathrm{~d}, 15.3)$ \\
\hline 9 & $7.38(\mathrm{~d}, 7.8)$ & $7.43(\mathrm{~d}, 7.7)$ & $7.44(\mathrm{~d}, 7.6)$ \\
\hline 10 & $6.95(\mathrm{dd}, 7.8,7.3)$ & $6.97(\mathrm{dd}, 7.7,7.2)$ & $7.09(\mathrm{dd}, 7.6,7.3)$ \\
\hline 11 & $7.02(\mathrm{dd}, 8.0,7.3)$ & $7.04(\mathrm{dd}, 8.0,7.2)$ & $7.13(\mathrm{dd}, 7.8,7.3)$ \\
\hline 12 & $7.26(\mathrm{~d}, 8.0)$ & $7.27(\mathrm{~d}, 8.0)$ & $7.26(\mathrm{~d}, 7.8)$ \\
\hline $14 \alpha$ & $2.10(\mathrm{~m})$ & $2.14(\mathrm{~m})$ & $2.01(\mathrm{~m})$ \\
\hline $14 \beta$ & $1.64(\mathrm{~m})$ & $1.66(\mathrm{~m})$ & $1.68(\mathrm{~m})$ \\
\hline 15 & 3.26 (br s) & 2.79 (br s) & 3.12 (br s) \\
\hline 16 & $\begin{array}{l}1.62(\mathrm{ddd}, 9.0,7.0 \\
0.9)\end{array}$ & $1.65(\mathrm{~m})$ & $\begin{array}{l}1.53 \text { (ddd, } 9.4,7.3 \text {, } \\
0.9 \text { ) }\end{array}$ \\
\hline 17 & $\begin{array}{l}2.80(\mathrm{ddd}, 12.1, \\
9.0,2.7)\end{array}$ & $\begin{array}{l}2.75(\mathrm{ddd}, 12.2 \\
9.2,2.8)\end{array}$ & $\begin{array}{l}2.95(\mathrm{ddd}, 11.6 \\
9.4,2.7)\end{array}$ \\
\hline 18 & $1.75(\mathrm{~d}, 6.9)$ & $1.71(\mathrm{~d}, 6.9)$ & $1.65(\mathrm{~d}, 6.8)$ \\
\hline 19 & $5.93(\mathrm{q}, 6.9)$ & $5.95(\mathrm{q}, 6.9)$ & $5.34(\mathrm{q}, 6.8)$ \\
\hline 21 & $4.96(\mathrm{~s})$ & $5.03(\mathrm{~s})$ & $3.55(2 \mathrm{H}, \mathrm{s})$ \\
\hline $22 \alpha$ & $2.41(\mathrm{br} \mathrm{d}, 12.3)$ & $2.43(\mathrm{br} \mathrm{d}, 12.5)$ & 2.47 (br d, 12.7) \\
\hline $22 \beta$ & $\begin{array}{l}2.12(\mathrm{dd}, 12.3, \\
12.1)\end{array}$ & $\begin{array}{l}1.95(\mathrm{dd}, 12.5 \\
12.2)\end{array}$ & $\begin{array}{l}1.92(\mathrm{dd}, 12.7, \\
11.6)\end{array}$ \\
\hline $24 \alpha$ & $\begin{array}{l}2.15(\mathrm{dd}, 13.0, \\
1.3)\end{array}$ & $\begin{array}{l}2.16(\mathrm{dd}, 13.3, \\
0.8)\end{array}$ & $\begin{array}{l}2.25(\mathrm{dd}, 13.1, \\
1.3)\end{array}$ \\
\hline $24 \beta$ & $2.26(\mathrm{~d}, 13.0)$ & $2.29(\mathrm{~d}, 13.3)$ & $2.12(\mathrm{~d}, 13.1)$ \\
\hline 26 & $0.95(\mathrm{~s})$ & $0.98(\mathrm{~s})$ & $0.99(\mathrm{~s})$ \\
\hline 27 & $1.19(\mathrm{~s})$ & $1.29(\mathrm{~s})$ & $1.19(\mathrm{~s})$ \\
\hline $1^{\prime}$ & $4.64(\mathrm{~d}, 7.9)$ & $4.65(\mathrm{~d}, 7.8)$ & \\
\hline $2^{\prime}$ & $3.29(\mathrm{~m})$ & $3.30(\mathrm{~m})$ & \\
\hline $3^{\prime}$ & $3.37(\mathrm{~m})$ & $3.37(\mathrm{~m})$ & \\
\hline $4^{\prime}$ & 3.28 (m, overlap) & 3.29 (m, overlap) & \\
\hline $5^{\prime}$ & 3.28 (m, overlap) & 3.29 (m, overlap) & \\
\hline $6^{\prime} \mathrm{a}$ & $\begin{array}{l}3.60(\mathrm{dd}, 11.9, \\
4.9)\end{array}$ & $\begin{array}{l}3.60(\mathrm{dd}, 11.9, \\
4.9)\end{array}$ & \\
\hline $6^{\prime} b$ & $\begin{array}{l}3.74(\mathrm{dd}, 11.9, \\
1.6)\end{array}$ & $3.76(\mathrm{br} \mathrm{d}, 11.9)$ & \\
\hline $1-\mathrm{NH}$ & & & $8.08(\mathrm{~s})$ \\
\hline
\end{tabular}

\footnotetext{
${ }^{a}$ Measured in methanol- $d_{4}(3.30 \mathrm{ppm})$

b Measured in $\mathrm{CDCl}_{3}$ (7.26 ppm)
} 
2,2-dimethyl-4-oxopiperidin-6-yl moiety by HMBC correlations (Fig. 1) from $\mathrm{H}-17$ to $\mathrm{C}-23, \mathrm{H}-22$ to $\mathrm{C}-23$ and $\mathrm{C}-24$, and $\mathrm{H}-24$ to $\mathrm{C}-22, \mathrm{C}-23, \mathrm{C}-25, \mathrm{C}-26$, and $\mathrm{C}-27$. The piperidinyl moiety was linked to $\mathrm{C}-16$ through $\mathrm{C}-16-\mathrm{C}-17$ bond by $\mathrm{HMBC}$ correlations from $\mathrm{H}-16$ to $\mathrm{C}-17$ and $\mathrm{C}-22$ and ${ }^{1} \mathrm{H}-{ }^{1} \mathrm{H}$ COSY correlation of $\mathrm{H}-16 / \mathrm{H}-17$ (Fig. 1).

The relative configuration of $\mathbf{1}$ was established by NMR analysis based on computer-generated 3D drawing with minimized energy by MM2 calculation (Fig. 2). ROESY correlations of $\mathrm{H}-16 \leftrightarrow \mathrm{H}-6 \beta / \mathrm{H}-14 \beta$ and $\mathrm{H}-5 \leftrightarrow \mathrm{H}-21$ suggested that $\mathbf{1}$ had the same stereochemistry as rauvotetraphylline B. The $E$-geometry of the ethylidene was indicated from ROESY correlations of $\mathrm{H}-15 \leftrightarrow \mathrm{Me}-18$ and $\mathrm{H}-19 \leftrightarrow \mathrm{H}-21$. The anti relationship of $\mathrm{H}-16$ and $\mathrm{H}-17$ was suggested by the large coupling constant $\left(J_{16,17}=9.0 \mathrm{~Hz}\right)$, which could also be explained by that the molecule favors the conformation in which larger substituents are in the anti position. This was further supported by ROESY correlations of $\mathrm{H}-17 \leftrightarrow \mathrm{Me}-18$. The $R^{*}$ configuration of $\mathrm{C}-17$ was implied by ROESY correlations of $\mathrm{H}-6 \beta \leftrightarrow \mathrm{H}-22 \beta$ and Me$18 \leftrightarrow$ Me-26 (Fig. 2). Another noteworthy observation is that the chemical shift of $\mathrm{H}-15\left(\delta_{\mathrm{H}} 3.26\right)$ in 1 was relatively

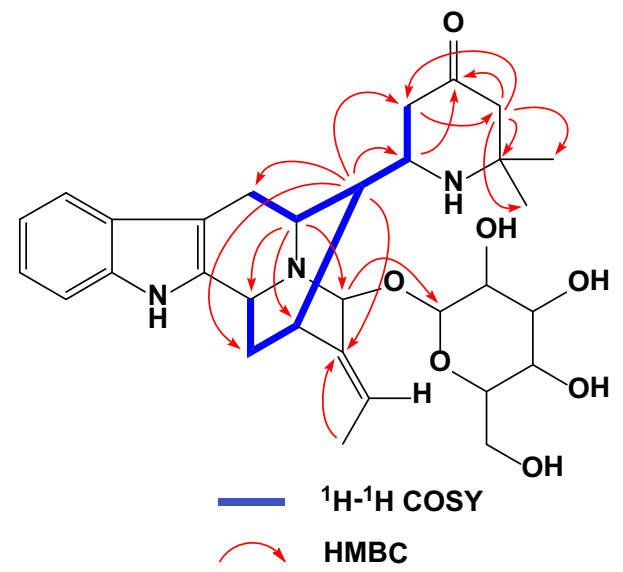

Fig. 1 Key HMBC and ${ }^{1} \mathrm{H}-{ }^{1} \mathrm{H}$ COSY correlations of $\mathbf{1}$ deshielded compared to that of $\mathrm{H}-15\left(\delta_{\mathrm{H}} 2.79\right)$ in its 17-epimer 2 (vide infra). This is attributed to paramagnetic deshielding caused by the proximity of the $\mathrm{NH}$ nitrogen atom to H-15 (Fig. 2). Thus, the structure of 1 was established as shown and named rauvotetraphylline F.

Compound 2, isolated as amorphous powder, had the same molecular formula as $\mathbf{1}$ based on HR-ESI-MS (pos.), showing a quasi-molecular ion peak at $\mathrm{m} / \mathrm{z}, 568.3031$ (calcd for $\mathrm{C}_{31} \mathrm{H}_{42} \mathrm{~N}_{3} \mathrm{O}_{7}, 568.3022$ ). The ${ }^{1} \mathrm{H}$ and ${ }^{13} \mathrm{C}$ NMR spectra of 2 (Tables 1 and 3 ) were very similar in all respects to those of 2 except for the chemical shifts of H-5, H-6 $\beta$, and $\mathrm{H}-15$ in the ${ }^{1} \mathrm{H}$ NMR spectrum. This discrepancy proved that compound $\mathbf{2}$ is a $\mathrm{C}-17$ epimer of $\mathbf{1}$ while applying the same analysis carried out for $\mathbf{1}$. The paramagnetic deshielding experienced by $\mathrm{H}-15$ in $\mathbf{1}$ was now experienced by $\mathrm{H}-5$ and $\mathrm{H}-6 \beta$ instead in 2 (Fig. 2), implying the $S^{*}$ configuration of $\mathrm{C}-17$. This was further verified by strong ROESY correlations between H-22 $\alpha$ and H-15/Me-18 and no correlation between Me-26 and Me-18. Therefore, the structure of 1 was elucidated as shown and named 17-epirauvotetraphylline $\mathrm{F}$.

Compound $\mathbf{3}$ was obtained as amorphous powder. Its HR-ESI-MS revealed an $[\mathrm{M}+\mathrm{H}]^{+}$peak at $\mathrm{m} / \mathrm{z} 390.2538$ (calcd for $\mathrm{C}_{25} \mathrm{H}_{32} \mathrm{~N}_{3} \mathrm{O}, 390.2545$ ), suggesting the molecular formula $\mathrm{C}_{25} \mathrm{H}_{31} \mathrm{~N}_{3} \mathrm{O}$. The NMR data (Tables 1 and 3) were closely related to those of $\mathbf{1}$ except for the signals of a methylene group in $\mathbf{3}$ instead of an oxygenated methine group in $\mathbf{1}$, and the absence of a series of glucose resonances. The configuration of $\mathrm{C}-17$ was designated as $R^{*}$ based on Me-18 showing ROESY correlation to Me-26, but no correlation to $\mathrm{H}-22$. Consequently, the structure of 3 was determined and named rauvotetraphylline G.

Compound 4 was isolated as amorphous powder. Its molecular formula was determined as $\mathrm{C}_{27} \mathrm{H}_{33} \mathrm{~N}_{3} \mathrm{O}_{3}$ by positive HR-ESI-MS at $\mathrm{m} / z \quad 448.2613$ (calcd for $\mathrm{C}_{27} \mathrm{H}_{34} \mathrm{~N}_{3} \mathrm{O}_{3}, 448.2600$ ). The ${ }^{13} \mathrm{C}$ NMR data (Table 3) were very similar to those of perakine [8]. The prominent difference between them was the aldehyde group in
Fig. 2 Key ROESY correlations of $\mathbf{1}$ and $\mathbf{2}$
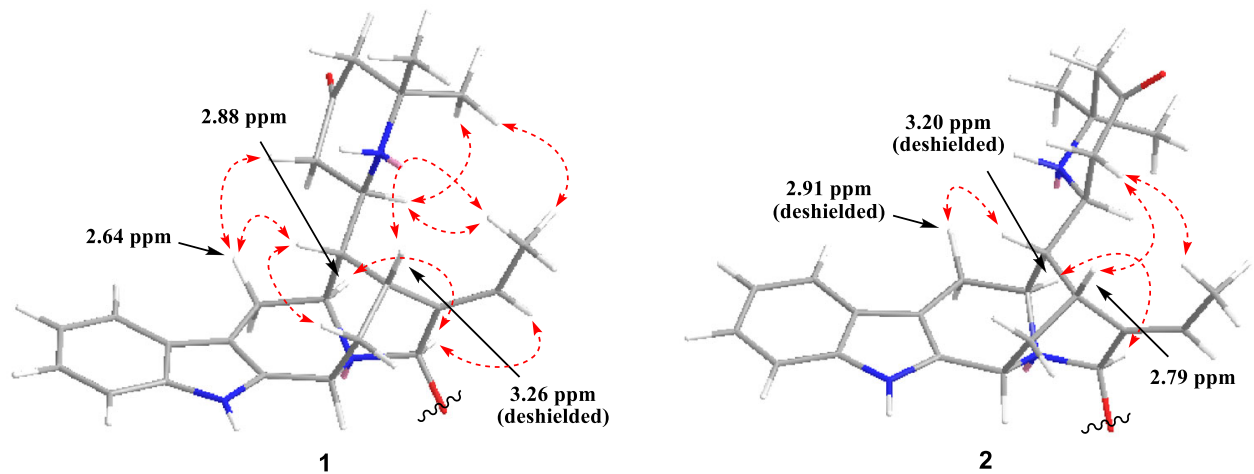
perakine changing into a 2,2-dimethyl-4-oxopiperidin-6-yl moiety $\left[\delta_{\mathrm{C}} 54.8(\mathrm{~d}), 47.2(\mathrm{t}), 210.4(\mathrm{~s}), 55.4(\mathrm{t}), 54.5(\mathrm{~s})\right.$, 25.2 (q), 32.2 (q)] on the basis of HMBC correlations (Fig. 3) from $\mathrm{H}-21$ to $\mathrm{C}-15$ and $\mathrm{C}-20, \mathrm{H}-22$ to $\mathrm{C}-20$, $\mathrm{C}-21, \mathrm{C}-23$, and $\mathrm{C}-24$, and $\mathrm{Me}-26$ to $\mathrm{C}-24, \mathrm{C}-25$, and C-27. The ROESY correlations (Fig. 4) of H-19↔H-3/H$14 \alpha, \mathrm{H}-14 \beta \leftrightarrow \mathrm{H}-17, \mathrm{Me}-18 \leftrightarrow \mathrm{H}-20$, and $\mathrm{H}-20 \leftrightarrow \mathrm{H}-5 / \mathrm{H}-16$ indicated that 4 possessed the same stereochemical characteristics as perakine. The $R^{*}$ configuration of C-21 was indicated by ROESY correlations of $\mathrm{H}-21 \leftrightarrow \mathrm{H}-14 \alpha / \mathrm{H}-19$, $\mathrm{H}-22 \alpha \leftrightarrow \mathrm{H}-19$, and $\mathrm{H}-22 \beta \leftrightarrow \mathrm{Me}-18$, which was further supported by comparison of the ${ }^{1} \mathrm{H}$ NMR spectra of $\mathbf{4}$ and its $\mathrm{C}-21$ epimer $\mathbf{5}$ (vide infra) (Table 2). The proximity of the $\mathrm{NH}$ nitrogen atom to $\mathrm{H}-15$ in $\mathbf{4}$ caused a marked downfield shift of $\mathrm{H}-15$ ( $\Delta=0.30 \mathrm{ppm}$ ) (Fig. 4). Hence, the structure of $\mathbf{4}$ was assigned as shown and named rauvotetraphylline $\mathrm{H}$.

Compound 5, obtained as amorphous powder, had the same molecular formula as $\mathbf{4}$, possessing a quasi-molecular ion peak at $m / z \quad 448.2602$ (calcd for $\mathrm{C}_{27} \mathrm{H}_{34} \mathrm{~N}_{3} \mathrm{O}_{3}$, 448.2600). The ${ }^{1} \mathrm{H}$ and ${ }^{13} \mathrm{C}$ NMR spectra of 5 (Tables 2 and 3) were almost identical to those of $\mathbf{4}$ except for the upfield shift of H-15 $(\Delta=-0.30 \mathrm{ppm})$ and downfield shifts of Me-18 ( $\Delta=0.15 \mathrm{ppm})$ and H-19 $(\Delta=0.11 \mathrm{ppm})$ in the ${ }^{1} \mathrm{H}$ NMR spectrum. This can be rationalized in terms of paramagnetic deshielding experienced by Me-18 and

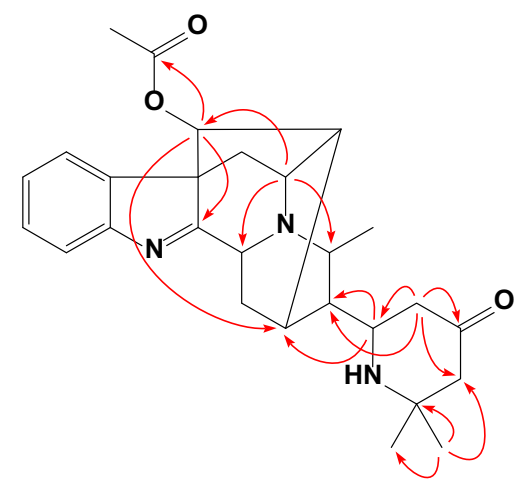

Fig. 3 Key HMBC correlations of $\mathbf{4}$
H-19 in 5 and $\mathrm{H}-15$ in 4 (Fig. 4), revealing the $S^{*}$ configuration of $\mathrm{C}-21$. This was further supported by significant ROESY correlation (Fig. 4) of H-22 $\alpha \leftrightarrow \mathrm{H}-15$ and no correlation of $\mathrm{H}-22 \alpha \leftrightarrow \mathrm{H}-19$ or $\mathrm{H}-22 \beta \leftrightarrow \mathrm{Me}-18$. Therefore, the structure of $\mathbf{5}$ was elucidated as shown and named 21-epi-rauvotetraphylline $\mathrm{H}$.

The contribution of artifacts on structural diversity of alkaloids from Rauvolfia species is not ignorable as acidic or basic conditions are often used during isolation process, in spite that many artifacts from this genus are generally

Table $2{ }^{1} \mathrm{H}$ NMR Data for Compounds 4 and 5 ( $\delta$ in ppm, $J$ in $\mathrm{Hz}$ )

\begin{tabular}{lll}
\hline No. & $\mathbf{4}$ & $\mathbf{5}$ \\
\hline 3 & $4.14(\mathrm{~d}, 9.7)$ & $4.16(\mathrm{~d}, 9.4)$ \\
5 & $3.64(\mathrm{dd}, 6.6,4.9)$ & $3.63(\mathrm{dd}, 6.1,4.8)$ \\
$6 \alpha$ & $1.60(\mathrm{~d}, 11.9)$ & $1.61(\mathrm{~d}, 11.9)$ \\
$6 \beta$ & $2.79(\mathrm{dd}, 11.9,4.9)$ & $2.78(\mathrm{dd}, 11.9,4.8)$ \\
9 & $7.47(\mathrm{~d}, 7.3)$ & $7.45(\mathrm{~d}, 7.3)$ \\
10 & $7.22(\mathrm{dd}, 7.6,7.3)$ & $7.20(\mathrm{dd}, 7.6,7.3)$ \\
11 & $7.39(\mathrm{dd}, 7.7,7.6)$ & $7.37(\mathrm{dd}, 7.7,7.6)$ \\
12 & $7.61(\mathrm{~d}, 7.7)$ & $7.60(\mathrm{~d}, 7.7)$ \\
$14 \alpha$ & $1.89(\mathrm{dd}, 14.7,9.7)$ & $1.83(\mathrm{dd}, 14.9,9.4)$ \\
$14 \beta$ & $1.52(\mathrm{dd}, 14.7,4.4)$ & $1.51(\mathrm{dd}, 14.9,3.1)$ \\
15 & $2.62(\mathrm{~m})$ & $2.32(\mathrm{~m}$, overlap) \\
16 & $2.34(\mathrm{dd}, 6.6,5.0)$ & $2.32(\mathrm{~m}$, overlap) \\
17 & $4.99(\mathrm{~s})$ & $4.95(\mathrm{~s})$ \\
18 & $1.29(\mathrm{~d}, 6.5)$ & $1.44(\mathrm{~d}, 6.4)$ \\
19 & $2.65(\mathrm{~m})$ & $2.76(\mathrm{~m})$ \\
20 & $1.25(\mathrm{~m})$ & $1.20(\mathrm{~m})$ \\
21 & $3.16(\mathrm{ddd}, 11.8,8.5,2.7)$ & $3.16(\mathrm{ddd}, 11.2,8.7,2.5)$ \\
$22 \alpha$ & $2.43(\mathrm{br} . \mathrm{d}, 12.9)$ & $2.52(\mathrm{br} . \mathrm{d}, 13.4)$ \\
$22 \beta$ & $2.12(\mathrm{dd}, 12.9,11.8)$ & $1.92(\mathrm{dd}, 13.4,11.2)$ \\
$24 \alpha$ & $2.28(\mathrm{br} . \mathrm{d}, 14.4)$ & $2.31(\mathrm{br} . \mathrm{d}, 13.5)$ \\
$24 \beta$ & $2.25(\mathrm{~d}, 14.4)$ & $2.19(\mathrm{~d}, 13.5)$ \\
26 & $1.06(\mathrm{~s})$ & $1.08(\mathrm{~s})$ \\
27 & $1.27(\mathrm{~s})$ & $1.28(\mathrm{~s})$ \\
OAc & $2.17(\mathrm{~s})$ & $2.16(\mathrm{~s})$ \\
\hline $\mathrm{Ne}$ &
\end{tabular}

Measured in $\mathrm{CDCl}_{3}(7.26 \mathrm{ppm})$
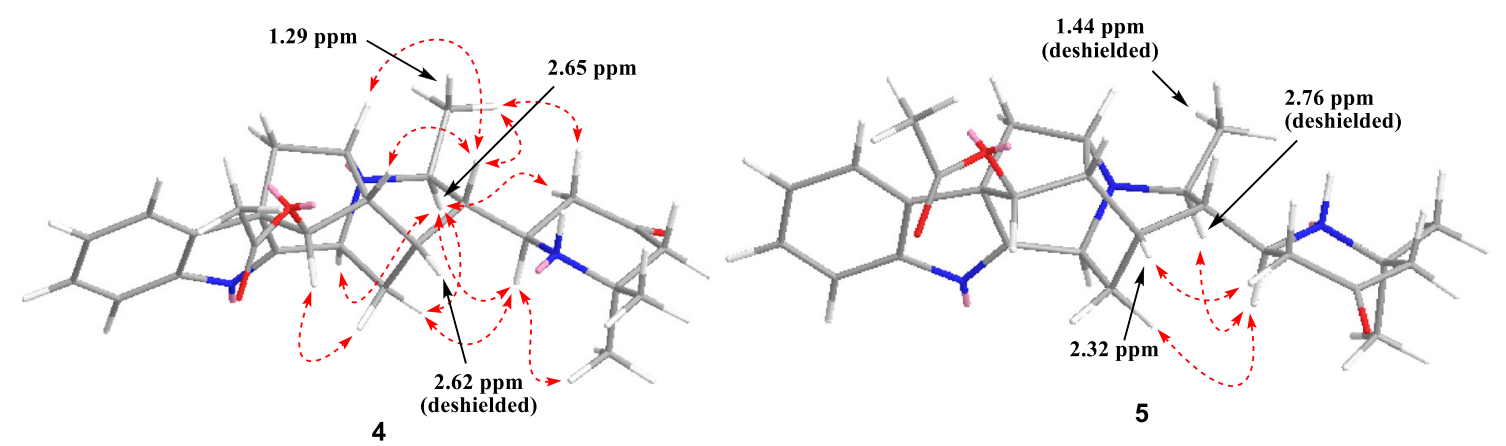

Fig. 4 Key ROESY correlations of $\mathbf{4}$ and 5 
presented in literatures as naturally occurring compounds [9]. Considering that the presence of aldehyde group at C-16/C-20 is common for sarpagine/perakine type alkaloids $[8,10,11]$, it's plausible to deduce that, like triacetonamine [12], a common artifact of plant extractions, the 2,2-dimethyl-4-oxopiperidine moiety might also be an artifact produced by reaction of aldehyde group with acetone/ammonia since the latter were used as eluents during the isolation procedures. These artifacts represent a unique type of sarpagine/perakine series bearing an unusual piperidine unit brought about by using common eluents.

All of the isolated compounds were evaluated for their in vitro growth inhibitory effects against five human tumor cell lines (HL-60, SMMC-7721, A-549, MCF-7 and SW480 ) with cisplatin and taxol serving as positive controls by the MTT method [13]. Regrettably, all tested compounds were inactive $\left(\mathrm{IC}_{50}\right.$ values $\left.>40 \mu \mathrm{M}\right)$.

\section{Experimental Section}

\subsection{General Experimental Procedures}

Optical rotations were measured on a Jasco P-1020 automatic digital polarimeter. UV data were obtained from online HPLC analysis. IR spectra (KBr) were obtained on a Bruker
Tensor-27 infrared spectrophotometer. NMR spectra were acquired with a Bruker DRX-500 or Bruker Avance III 600 instrument (Bruker BioSpin GmbH, Rheinstetten, Germany) with deuterated solvent signals used as internal standards. ESI-MS (including HR-ESI-MS) were measured on API QSTAR Pulsar i mass spectrometers. Silica gel (200-300 mesh, Qingdao Marine Chemical Inc., China) and Sephadex LH-20 (Amersham Biosciences, Sweden) were used for column chromatography. Medium pressure liquid chromatography (MPLC) was performed on a Büchi Sepacore System equipping with pump manager C-615, pump modules C-605, and fraction collector C-660 (Büchi Labortechnik AG, Switzerland), and columns packed with Chromatorex C-18 (40-75 $\mu$ m, Fuji Silysia Chemical Ltd., Japan). Fractions were monitored by TLC (Qingdao Marine Chemical Inc., China) in combination with reversed-phase HPLC (Agilent 1200, Extend-C18 column, $5 \mu \mathrm{m}, 4.6 \times 150 \mathrm{~mm}$ ).

\subsection{Plant Material}

The aerial parts of Rauvolfia tetraphylla were collected in Xiaomenglun of Yunnan Province, China, in June 2010 and identified by Mr. Yu Chen of Kunming Institute of Botany, Chinese Academy of Sciences. The voucher specimen (No. BBP0234020RT) was deposited at BioBioPha Co., Ltd.

Table $3{ }^{13} \mathrm{C}$ NMR Data for Compounds $\mathbf{1}-\mathbf{5}$ ( $\delta$ in ppm)

\begin{tabular}{|c|c|c|c|c|c|}
\hline No. & $1^{\mathrm{a}}$ & $2^{\mathrm{a}}$ & $3^{\mathrm{b}}$ & $4^{b}$ & $5^{\mathrm{b}}$ \\
\hline 2 & $139.7(\mathrm{~s})$ & $139.0(\mathrm{~s})$ & $138.3(\mathrm{~s})$ & $183.2(\mathrm{~s})$ & $183.2(\mathrm{~s})$ \\
\hline 3 & 44.6 (d) & $44.8(\mathrm{~d})$ & $50.0(\mathrm{~d})$ & $56.8(\mathrm{~d})$ & 56.8 (d) \\
\hline 5 & 53.4 (d) & $55.4(\mathrm{~d})$ & $54.8(\mathrm{~d})$ & 50.7 (d) & 50.8 (d) \\
\hline 6 & $28.3(\mathrm{t})$ & $28.9(\mathrm{t})$ & $27.6(\mathrm{t})$ & $37.6(t)$ & $37.6(t)$ \\
\hline 7 & $104.0(\mathrm{~s})$ & $104.5(\mathrm{~s})$ & $103.9(\mathrm{~s})$ & 64.8 (s) & $64.8(\mathrm{~s})$ \\
\hline 8 & $128.9(\mathrm{~s})$ & $128.9(\mathrm{~s})$ & $127.5(\mathrm{~s})$ & $136.3(\mathrm{~s})$ & $136.3(\mathrm{~s})$ \\
\hline 9 & $118.5(\mathrm{~d})$ & $118.7(d)$ & $117.9(\mathrm{~d})$ & $123.8(\mathrm{~d})$ & $123.8(\mathrm{~d})$ \\
\hline 10 & 119.7 (d) & 119.7 (d) & $119.4(\mathrm{~d})$ & $125.4(\mathrm{~d})$ & $125.4(d)$ \\
\hline 11 & $121.9(\mathrm{~d})$ & $122.0(\mathrm{~d})$ & $121.4(\mathrm{~d})$ & $128.6(d)$ & $128.6(d)$ \\
\hline 12 & $111.9(\mathrm{~d})$ & $112.0(\mathrm{~d})$ & $110.9(\mathrm{~d})$ & $120.9(\mathrm{~d})$ & 120.9 (d) \\
\hline 13 & $138.2(\mathrm{~s})$ & $138.3(\mathrm{~s})$ & $136.3(\mathrm{~s})$ & $156.5(\mathrm{~s})$ & $156.5(\mathrm{~s})$ \\
\hline 14 & $34.7(\mathrm{t})$ & $34.8(\mathrm{t})$ & $34.5(\mathrm{t})$ & $22.0(\mathrm{t})$ & $22.2(\mathrm{t})$ \\
\hline 15 & 29.2 (d) & $29.3(\mathrm{~d})$ & $27.4(\mathrm{~d})$ & 27.2 (d) & 27.0 (d) \\
\hline 16 & $48.5(\mathrm{~d})$ & $48.2(\mathrm{~d})$ & 48.1 (d) & $49.2(\mathrm{~d})$ & 49.4 (d) \\
\hline 17 & $56.5(\mathrm{~d})$ & $57.6(d)$ & $54.8(\mathrm{~d})$ & 78.3 (d) & 78.2 (d) \\
\hline 18 & $14.3(\mathrm{q})$ & $13.8(q)$ & $13.6(q)$ & $20.4(q)$ & $21.3(q)$ \\
\hline 19 & $125.2(\mathrm{~d})$ & 124.9 (d) & 116.4 (d) & 53.1 (d) & 55.7 (d) \\
\hline 20 & $137.6(\mathrm{~s})$ & $137.4(\mathrm{~s})$ & $135.8(\mathrm{~s})$ & 49.4 (d) & 49.4 (d) \\
\hline 21 & 91.7 (d) & 91.7 (d) & $56.0(\mathrm{t})$ & $51.8(\mathrm{~d})$ & 53.7 (d) \\
\hline 22 & $47.4(\mathrm{t})$ & $48.2(\mathrm{t})$ & $47.2(\mathrm{t})$ & $47.8(\mathrm{t})$ & $48.0(\mathrm{t})$ \\
\hline 23 & $213.2(\mathrm{~s})$ & $212.9(\mathrm{~s})$ & $210.4(\mathrm{~s})$ & 209.6 (s) & 209.4 (s) \\
\hline 24 & $55.7(\mathrm{t})$ & $55.6(\mathrm{t})$ & $55.4(\mathrm{t})$ & $54.6(\mathrm{t})$ & $55.1(\mathrm{t})$ \\
\hline
\end{tabular}


Table 3 continued

\begin{tabular}{|c|c|c|c|c|c|}
\hline No. & $1^{\mathrm{a}}$ & $2^{\mathrm{a}}$ & $3^{\mathrm{b}}$ & $4^{b}$ & $5^{\mathrm{b}}$ \\
\hline 25 & $55.5(\mathrm{~s})$ & $55.6(\mathrm{~s})$ & $54.5(\mathrm{~s})$ & $54.0(\mathrm{~s})$ & $54.5(\mathrm{~s})$ \\
\hline 26 & $25.6(q)$ & $25.4(q)$ & $25.2(q)$ & $25.4(q)$ & $25.4(q)$ \\
\hline 27 & $31.9(\mathrm{q})$ & $31.8(q)$ & $32.2(q)$ & $32.1(q)$ & $32.2(q)$ \\
\hline $1^{\prime}$ & $103.2(\mathrm{~d})$ & $103.3(\mathrm{~d})$ & & & \\
\hline $2^{\prime}$ & 75.4 (d) & $75.3(\mathrm{~d})$ & & & \\
\hline $3^{\prime}$ & 78.0 (d) & $78.0(\mathrm{~d})$ & & & \\
\hline $4^{\prime}$ & 71.4 (d) & $71.5(\mathrm{~d})$ & & & \\
\hline $5^{\prime}$ & 77.9 (d) & $78.0(\mathrm{~d})$ & & & \\
\hline $6^{\prime}$ & $62.7(\mathrm{t})$ & $62.7(\mathrm{t})$ & & & \\
\hline $\mathrm{CH}_{3} \mathrm{COO}$ & & & & $21.1(q)$ & $21.1(q)$ \\
\hline $\mathrm{CH}_{3} \mathrm{COO}$ & & & & $170.1(\mathrm{~s})$ & $170.0(\mathrm{~s})$ \\
\hline
\end{tabular}

${ }^{\text {a }}$ Measured in methanol- $d_{4}(49.0 \mathrm{ppm})$

b Measured in $\mathrm{CDCl}_{3}$ (77.0 ppm)

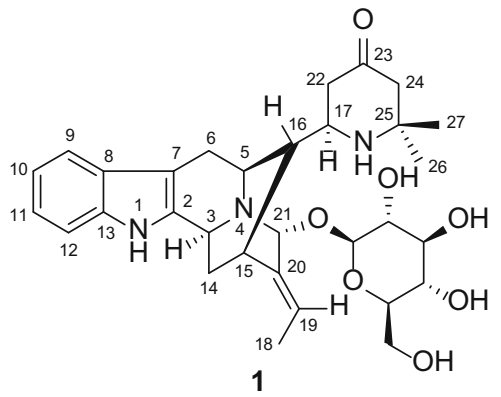

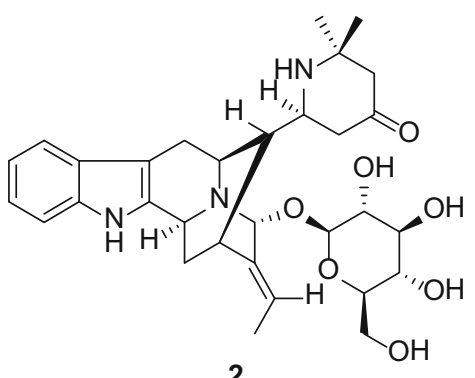

2

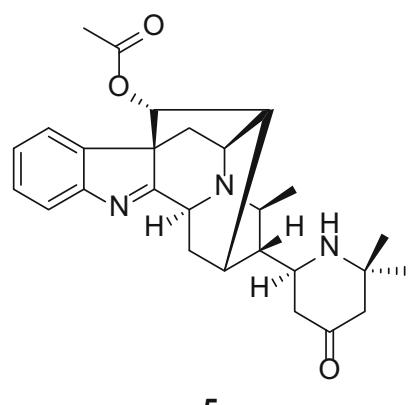

5

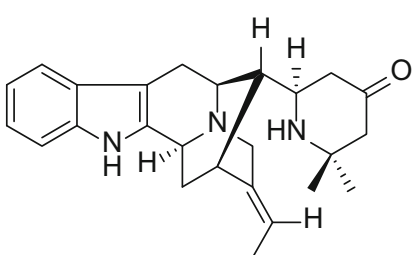

3

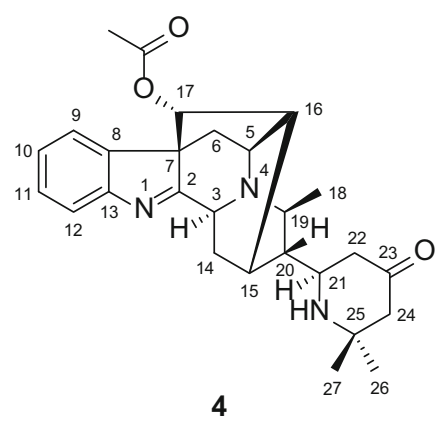

Structures of Compounds 1-5

\subsection{Extraction and Isolation}

The air-dried and powdered aerial parts of $R$. tetraphylla $(7.5 \mathrm{~kg})$ were extracted three times with $\mathrm{EtOH}-\mathrm{H}_{2} \mathrm{O}$ $(95: 5, \mathrm{v} / \mathrm{v} ; 3 \times 20 \mathrm{~L}$, each 5 days) at room temperature, and the solvent was removed under reduced pressure to give crude extract (ca. $400 \mathrm{~g}$ ), which was then fractionated by silica gel column chromatography (CC) eluted with a gradient solvent system (containing $0.2 \%$ ammonia) of petroleum ether-acetone and then $\mathrm{MeOH}$ to yield seven fractions A-G. Fraction D, eluted by acetone, was separated on silica gel $\mathrm{CC}\left(\mathrm{CHCl}_{3}-\mathrm{MeOH}-\right.$ ammonia, 100:1:0.5 $\rightarrow$ 0:100:0.5) to give three subfractions D1-D3. Fraction D1 was purified further by silica gel $\mathrm{CC}\left(\mathrm{CHCl}_{3}-\mathrm{MeOH}-\mathrm{ammonia}, 50: 1: 0.1\right)$ and then prep. TLC $\left(\mathrm{CHCl}_{3}-\mathrm{MeOH}\right.$-ammonia, 10:1:0.1) to afford $4(9 \mathrm{mg})$ and $\mathbf{5}(6 \mathrm{mg})$. Fraction D2 was separated by silica gel $\mathrm{CC}\left(\mathrm{CHCl}_{3}-\mathrm{MeOH}-\mathrm{ammonia}, 40: 1: 0.1\right)$ and then prep. TLC $\left(\mathrm{CHCl}_{3}-\mathrm{MeOH}-\right.$ ammonia, $\left.9: 1: 0.1\right)$ to afford $3(10 \mathrm{mg})$. Fraction $\mathrm{G}$, eluted by $\mathrm{MeOH}$, was separated further by silica gel $\mathrm{CC}\left(\mathrm{CHCl}_{3}-\mathrm{MeOH}-\mathrm{am}\right.$ monia, 10:1:0.1 $\rightarrow$ 0:10:0.1), repeated MPLC $(40 \rightarrow$ $45 \% \mathrm{MeOH}$ in $\mathrm{H}_{2} \mathrm{O}$ ), and then Sephadex LH-20 $(\mathrm{MeOH})$ to afford $\mathbf{1}(72 \mathrm{mg})$ and $2(26 \mathrm{mg})$. 


\subsection{Rauvotetraphylline F (1)}

White amorphous powder; $[\alpha]_{\mathrm{D}}^{15}+10.1\left(c 0.19, \mathrm{CHCl}_{3}\right)$; $\mathrm{UV}(\mathrm{MeOH}) \lambda_{\max }: 225,281,290(\mathrm{sh}) \mathrm{nm}$; IR $(\mathrm{KBr}) v_{\max }$ 3404, 2961, 2921, 1700, 1470, 1453, 1384, 1338, 1320, 1302, 1076, 1031, $745 \mathrm{~cm}^{-1} ;{ }^{1} \mathrm{H}$ and ${ }^{13} \mathrm{C}$ NMR data see Tables 1 and 3; ESI-MS (pos.): $m / z 568[\mathrm{M}+\mathrm{H}]^{+}$; HRESI-MS (pos.): $\mathrm{m} / \mathrm{z} 568.3025$ (calcd for $\mathrm{C}_{31} \mathrm{H}_{42} \mathrm{~N}_{3} \mathrm{O}_{7}$, 568.3022).

\subsection{7-epi-Rauvotetraphylline F (2)}

White amorphous powder; $[\alpha]_{\mathrm{D}}^{16}+14.9\left(c 0.20, \mathrm{CHCl}_{3}\right)$; UV (MeOH) $\lambda_{\max }: 225,281,290(\mathrm{sh}) \mathrm{nm}$; IR (KBr) $v_{\max }$ 3396, 2962, 2923, 1699, 1626, 1471, 1451, 1384, 1337, 1300, 1075, 1030, $746 \mathrm{~cm}^{-1} ;{ }^{1} \mathrm{H}$ and ${ }^{13} \mathrm{C}$ NMR data see Tables 1 and 3; ESI-MS (pos.): $m / z 568[\mathrm{M}+\mathrm{H}]^{+}$; HRESI-MS (pos.): $\mathrm{m} / \mathrm{z} 568.3031$ (calcd for $\mathrm{C}_{31} \mathrm{H}_{42} \mathrm{~N}_{3} \mathrm{O}_{7}$, 568.3022).

\subsection{Rauvotetraphylline G (3)}

White amorphous powder; $[\alpha]_{\mathrm{D}}^{14}-22.4\left(c 0.19, \mathrm{CHCl}_{3}\right)$; $\mathrm{UV}(\mathrm{MeOH}) \lambda_{\max }: 225,280,290$ (sh) nm; IR (KBr) $v_{\max }$ 3421, 3143, 3057, 2961, 2925, 2855, 1705, 1626, 1473, 1301, 1240, 1169, $741 \mathrm{~cm}^{-1} ;{ }^{1} \mathrm{H}$ and ${ }^{13} \mathrm{C}$ NMR data see Tables 1 and 3; ESI-MS (pos.): $m / z 390[\mathrm{M}+\mathrm{H}]^{+}$; HRESI-MS (pos.): $\mathrm{m} / \mathrm{z} 390.2538$ (calcd for $\mathrm{C}_{25} \mathrm{H}_{32} \mathrm{~N}_{3} \mathrm{O}$, 390.2545).

\subsection{Rauvotetraphylline H (4)}

White amorphous powder; $[\alpha]_{\mathrm{D}}^{14}+9.9\left(c 0.20, \mathrm{CHCl}_{3}\right)$; UV $(\mathrm{MeOH}) \lambda_{\max }: 220,262 \mathrm{~nm}$; IR (KBr) $v_{\max } 3433,2965$, 2934, 1741, 1707, 1592, 1453, 1380, 1364, 1295, 1033, $773,753 \mathrm{~cm}^{-1} ;{ }^{1} \mathrm{H}$ and ${ }^{13} \mathrm{C}$ NMR data see Tables 2 and 3; ESI-MS (pos.): $m / z 448[\mathrm{M}+\mathrm{H}]^{+}$; HR-ESI-MS (pos.): $\mathrm{m} / \mathrm{z}, 448.2613$ (calcd for $\mathrm{C}_{27} \mathrm{H}_{34} \mathrm{~N}_{3} \mathrm{O}_{3}, 448.2600$ ).

\subsection{7-epi-Rauvotetraphylline H (5)}

White amorphous powder; $[\alpha]_{\mathrm{D}}^{15}+47.3\left(c \quad 0.20, \mathrm{CHCl}_{3}\right)$; UV (MeOH) $\lambda_{\max }: 220,263 \mathrm{~nm}$; IR (KBr) $v_{\max } 3433,2965$, 2936, 1742, 1707, 1592, 1453, 1376, 1268, 1230, 1177, 1032, 774, $753 \mathrm{~cm}^{-1} ;{ }^{1} \mathrm{H}$ and ${ }^{13} \mathrm{C}$ NMR data see Tables 2 and 3; ESI-MS (pos.): $m / z, 448[\mathrm{M}+\mathrm{H}]^{+}$; HR-ESI-MS (pos.): $m / z 448.2602$ (calcd for $\mathrm{C}_{27} \mathrm{H}_{34} \mathrm{~N}_{3} \mathrm{O}_{3}, 448.2600$ ).
3.9 Cytotoxicity Bioassay

The cytotoxicity assay was performed according to an MTT [3-(4,5-dimethylthiazol-2-yl)-2,5-diphenyltetrazolium bromide] method [14], by use of the following five human cancer cell lines: HL-60, SMMC-7721, A-549, MCF-7, and SW-480. The $\mathrm{IC}_{50}$ values were calculated by Reed and Muench's method [15].

Acknowledgments This work was financially supported by "Largescale Compound Library" Project of National Development and Reform Commission of China.

\section{Compliance with Ethical Standards}

Conflict of Interest The authors declare no conflict of interest.

Open Access This article is distributed under the terms of the Creative Commons Attribution 4.0 International License (http:// creativecommons.org/licenses/by/4.0/), which permits unrestricted use, distribution, and reproduction in any medium, provided you give appropriate credit to the original author(s) and the source, provide a link to the Creative Commons license, and indicate if changes were made.

\section{References}

1. Editorial Committee of Flora of China, Flora of China (Science Press, Beijing, 1995), p. 157

2. D.L. Bemis, J.L. Capodice, P. Gorroochurn, A.E. Katz, R. Buttyan, Int. J. Oncol. 29, 1065-1073 (2006)

3. C.W. Wright, J.D. Phillipson, S.O. Awe, G.C. Kirby, D.C. Warhurst, J. Quetin-Leclercq, L. Angenot, Phytother. Res. 10, 361-363 (1996)

4. N.J. Martin, S.F. Ferreiro, F. Barbault, M. Nicolas, G. Lecellier, C. Paetz, M. Gaysinski, E. Alonso, O.P. Thomas, L.M. Botana, P. Raharivelomanana, Phytochemistry 109, 84-95 (2015)

5. N. Neuss, Indole and Biogenetically Related Alkaloids, vol. Chapter 17 (Academic Press, New York, 1980)

6. Y. Gao, D.S. Zhou, L.M. Kong, P. Hai, Y. Li, F. Wang, J.K. Liu, Nat. Prod. Bioprospect. 2, 65-69 (2012)

7. R. Verpoorte, J. Nat. Prod. 49, 1-25 (1986)

8. L. Li, H.P. He, H. Zhou, X.J. Hao, Nat. Prod. Res. Dev. 19, 235-239 (2007)

9. M. Lounasmaa, P. Hanhinen, J. Nat. Prod. 63, 1456-1460 (2000)

10. R. Sheludko, I. Gerasimenko, H. Kolshorn, J. Stöckigt, J. Nat. Prod. 65, 1006-1010 (2002)

11. L. Katoa, R.M. Bragaa, I. Kochb, L.S. Kinoshitab, Phytochemistry 60, 315-320 (2002)

12. L.F. Bjeldanes, G.W. Chang, J. Agric. Food Chem. 23, 1010-1011 (1975)

13. J.L. Pousset, J. Poisson, L. Olivier, J. Le Men, M.M. Janot, C.R. Acad, Science 261, 5538 (1965)

14. T.J. Mosmann, Immunol. Methods 65, 55-63 (1983)

15. L.J. Reed, H. Muench, Am. J. Hyg. 27, 493-497 (1938) 